\title{
Neighborhood and postal worker characteristics associated with dog bites in postal workers of the Brazilian National Postal Service in Curitiba
}

\author{
Características do bairro e de carteiros associadas com mordidas \\ de cães em trabalhadores postais dos Correios em Curitiba
}

\author{
Eduardo Alexandre de Oliveira ${ }^{1}$ \\ Rose Maria Manosso ${ }^{2}$ \\ Gisela Braune ${ }^{2}$ \\ Priscila Cavalheiro Marcenovicz ${ }^{1}$ \\ Leandro Nagae Kuritza ${ }^{1}$ \\ Henrique Larsen Brunow Ventura ${ }^{1}$ \\ Igor Adolfo Dexheimer Paploski ${ }^{1}$ \\ Mariana Kikuti ${ }^{1}$ \\ Alexander Welker Biondo
}

${ }^{1}$ Departamento de Medicina Veterinária, Universidade Federal do Paraná. Rua dos Funcionários 1540, Juveve. 80035-050 Curitiba PR. abiondo@illinois.edu ${ }^{2}$ Setor de Segurança, Medicina e Engenharia do trabalho, Correios do Brasil.

\begin{abstract}
Dog bites are the third most common cause of absenteeism among postal workers of the Brazilian National Postal Service in Southern Brazil, with an average off-work time of approximately two days for each biting episode. The objective of this study was to evaluate the neighborhood characteristics involving dog bites that occurred during work time in postal workers, its impact on work and consequent preventive alternatives. A descriptive and analytical cross-sectional study was designed for all Curitiba postal workers. Data were descriptively analyzed and the hypothesis of correlation between median monthly income, population density and occurrence of dog bites was tested. A total of $34.9 \%$ of the postal workers answered the questionnaire and $64.6 \%$ of them had been bitten while working. The odds of bites occurring in a neighborhood increase by 1.035 times for every increase in one unit in the population density and decrease by 0.998 times for every increase of US\$ 1.00 in the neighborhood median monthly income of the head of the family. The occurrence of dog bites among postal workers in Curitiba is related to income and population density and prevention strategies should address mailbox position and adequate fencing to provide protection for postal workers.
\end{abstract}

Key words Dog bites, Public health, Zoonosis
Resumo Mordidas de cães são a terceira causa mais frequente de absenteísmo ao trabalho em carteiros do Correio no sul do Brasil, com uma média de dois dias de ausência a cada episódio de mordida. O objetivo deste estudo foi avaliar as características de bairros onde ocorreram mordidas de cães em carteiros durante o período de serviço, o impacto disto no trabalho e desenvolver alternativas preventivas. Um corte-transversal descritivo e analítico foi desenhado e aplicado a todos os carteiros de Curitiba. Os dados foram analisados de forma descritiva e foi testada a hipótese de que renda mediana mensal, densidade populacional e ocorrência de mordidas em cada bairro estão correlacionadas. Um total de 34,9\% dos carteiros de Curitiba respondeu ao questionário e $64,6 \%$ deles já haviam sido mordidos enquanto trabalhavam. A chance de ocorrerem mordidas em um bairro aumenta em 1,035 vezes a cada aumento em uma unidade na densidade populacional e diminui 0,998 vezes para cada aumento de US\$ 1,00 na renda mediana mensal do chefe de família. A ocorrência de mordidas de cães em carteiros de Curitiba está correlacionada com renda e densidade populacional. Estratégias de prevenção devem visar um adequado posicionamento da caixa de correio e a instalação de cercas adequadas para proteger os carteiros.

Palavras-chave Mordidas de cães, Saúde pública, Zoonoses 


\section{Introduction}

Although pet ownership may provide several benefits such as increased self-confidence and selfesteem, responsibility, autonomy and has been used even in therapeutic purposes, a lack of responsible pet ownership may cause personal injuries such as traffic accidents, infectious diseases and dog bites ${ }^{1-9}$.

Dog bites are particularly damaging when analyzed under a work-related accident perspective $^{10}$. The impact that job accidents produce is often neglected and difficult to measure. The range of professionals who can be affected and the impact on them may be extensive and include post-traumatic stress symptoms, attention or memory problems and emotional interference on productivity ${ }^{11}$.

Injuries caused by dog bites leading to medical assistance have been described for more than two centuries ${ }^{12}$. In the United States of America, dog bites annually affect $1.5 \%$ of the entire population, representing an important public health problem ${ }^{13}$. Dogs are also the main animal species involved in bite events in Brazil, followed by cats and bats ${ }^{14}$. Moreover, dog bites are considered the third most common cause of job absence of postal workers in Parana State, Southern Brazil, with 1,098 communications of job accidents involving dog bites in 2007 alone (Brazilian National Mail Service - personal communication). The average time of postal workers job absence after a dog bite in Parana State is approximately two days. Apparently, the need for hospitalization increases with the age of the person bitten. Almost $50 \%$ of people over 75 years of age hospitalized due to dog bite stayfor eight or more days in the hospital ${ }^{15}$.

In Brazil, mail boxes are usually located in a wall or fence, but adequate fencing is not always available, and roaming dogs are easily found in Brazil, which may impair the regular postal worker job. Dog bites inflict losses and delays to mail services since the replacement postal worker needs to be trained, particularly in finding the houses of the new working area ${ }^{16}$.

Dog bites may potentially cause several zoonotic diseases such as rabies or complications due to contaminants from the animal saliva or environment into bitten person's skin. Once colonized into the wound, infectious agents may spread to other body areas, causing severe complications and even death ${ }^{17,18}$.

Brazil has no public healthcare system for pets to date. Since veterinary care is not generally af- fordable to low income populations, certain preventable pet diseases may be related to low socioeconomic status due to lack of vaccination. A positive association has been found between the average poverty rate and the average number of infectious disease notifications in dogs and cats $^{19}$. The influence of neighborhood income and population density status may be also related to dog bite occurrence; however no study has been conducted to study these associations and therefore such association remains to be established.

Since almost $40 \%$ of the dog population in Brazil have some degree of outdoor access ${ }^{20}$, particularly in low income neighborhoods, the Brazilian National Mail Service has been increasingly concerned on postal workers exposure to dogs in such areas. Accordingly, the primary aim of this study was to evaluate the prevalence of postal workers that were previously bitten during work. Secondary aims were to evaluate neighborhood characteristics that are associated with occurrence and number of dog bites in postal workers, the characteristics of dog bites and perception of zoonoses and responsible ownership by the postal workers, and finally to provide potential alternatives to effectively prevent dog bites.

\section{Methods}

The study was conducted in Curitiba, capital of Paraná state and currently the eighth most populated city in Brazil, with approximately 1.75 million inhabitants ${ }^{21}$. Based on the primary aim, a cross-sectional study was designed for the total population of 811 postal workers, requiring a sample size of 261 individuals for estimating the prevalence of postal workers bitten while working in the population with a precision of $5 \%$. Since true prevalence was unknown, a conservative expected prevalence of $50 \%$ was used for sample calculation ${ }^{22}$. The eligibility criteria for joining the study wereto be a postal worker and voluntarily answer respective questionnaires in Portuguese within a month. All Curitiba postal workers were asked to participate as volunteers of this project. Questions concerning dog bites included whether they have been bitten by dogs (closed question), in which neighborhood (open question), the body part wounded (closed question), and their previous knowledge on zoonoses transmitted by animal bites (open question). The questionnaire data were inserted into publicly available database software (Epi-Info, version 3.5.1, Centers for Diseases Control and Prevention, 
Atlanta, USA) and descriptive analysis was performed. The main outcome (dog bites) were summed for all neighborhoods and was analyzed for correlation with monetary median monthly income (median of income in US\$ dollars received by the chief of the household per month) and population density (inhabitants/hectare) using linear (quantitative data) and logistic (qualitative data) regression models. The income of the chief of the household was obtained from the 2000 Brazilian National Census. The definition of chief of the household was the person living a given household that is recognized as so by other people in the household. Further analysis shows that his correlates with authority, responsibility for family business and, in most cases, the most important source of livelihood. Data regarding population density status were obtained from Curitiba Urban Planning and Research Institute ${ }^{23}$. Monetary median income was converted from Brazilian currency (Real, R\$) to U.S. dollars (US\$) using January $27^{\text {th }} 2011$ exchange rate (US\$ $1.00=\mathrm{R} \$ 1.60)$. A p-value $<0.05$ was used as criteria for a significant difference.

\section{Results}

The number of bites suffered while working for the postal service, median monthly income of the family chief and population density in neighborhoods of Curitiba are presented (Figure 1). When analyzed under a linear regression model, the demographic data were not able to explain the number of reported bites according to the neighborhood $\left(r^{2}=0.16\right)$. However, when analyzed under the logistic regression model, both population density and median monthly income of the family chief were associated with the occurrence of bites in a given neighborhood. The odds of occurring bites in a neighborhood are increased 1.035 (95\% CI, 1.008-1.064; $\mathrm{p}=0.01$ ) times for every increase in one unit in the population density (number of people/hectare). On the other hand, the oddsof occurring bites are decreased 0.998 (95\% CI, 0.997-0.999; p < 0.04) times for every increase in US\$ 1.00 in the neighborhood median monthly income of the family chiefs.

A total of 283/811 (34.9\%) postal workers of Curitiba answered the questionnaires. A total of 197/283 (69.6\%) postal workers have been bitten at least once during working hours. A total of 61/ 197 (31.0\%) workers reported being bitten once, 48/197 (24.4\%) reported being bitten twice, 34/

\section{Number of reports of biting episodes per neighborhood}

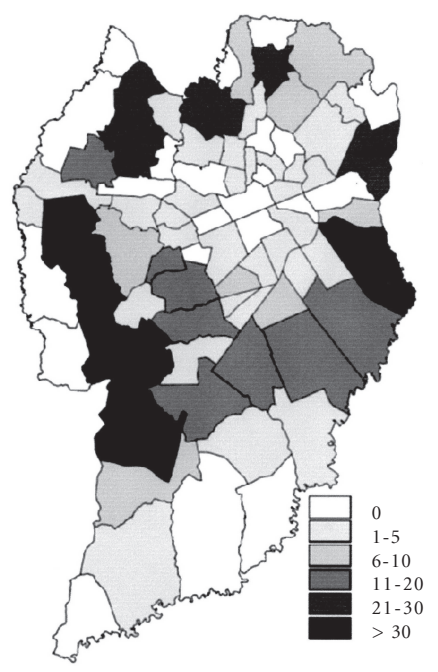

Median monthly income of the family chief per neighborhood (U.S. dollars)

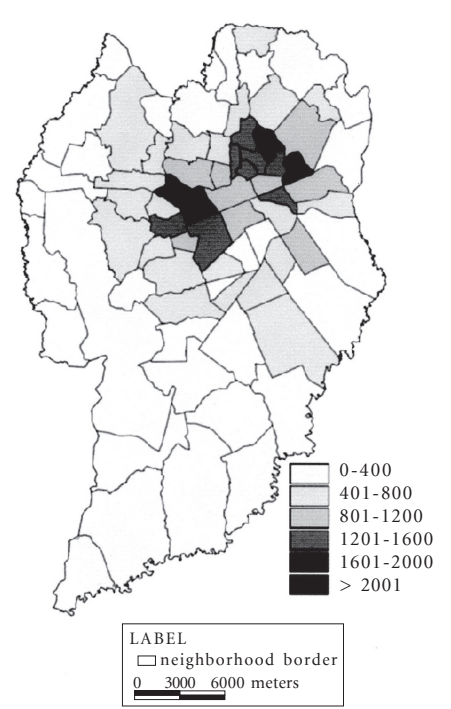

Population density per neighborhood (inhabitants/hectare)

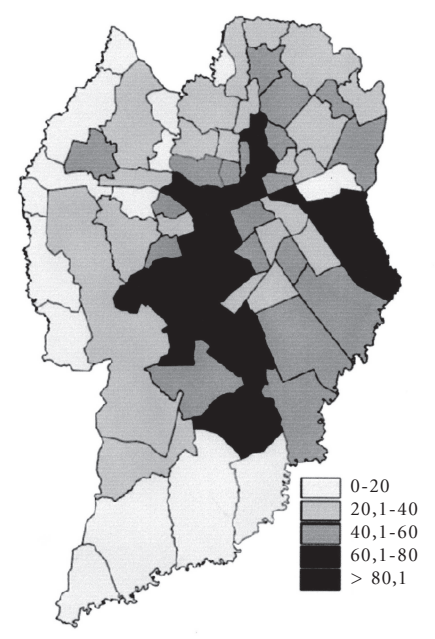

Figure 1. Maps of Curitiba neighborhoods according to its classification regarding the number ofreports of biting episodes per neighborhood, median monthly income of the family chief and population density. 
197 (17.3\%) reported being bitten three times, $35 / 197$ (17.8\%) reported being bitten more than three times and 19/197 (9.6\%) reported being bitten while working but did not specify how many times. A total of 474biting events were reported. Excluding postal workers that were not bitten and those that did not report how many times they were bitten, a mean of $2.7 \pm$ a standard deviation of 2.5 bites per postal worker was identified. There were reports of postal workers who were bitten in more than one body region in a single attack, as well as in more than one situation. Regarding where in body did the biting episode happened, a total of 123/197 (62.4\%) postal workers reported dog bites in the hands or feet, 99/197 (50.3\%) in the legs, 29/197 (14.7\%) in the arms, nine in the trunk and only one in the neck/head. Interestingly, 84/283 (29.7\%) postal workers reported that the animal involved in different accident situations was not the same, making difficult to identify one specific aggressive animal. Communication of dog bite accident to the Post Office was made by 189/197 (95.9\%). Moreover, 96/197 (48.7\%) postal workers were bitten during the mail delivery to houses which had mailboxes considered by the postal workers as properly installed. Data regarding the postal workers that were bitten are shown in Table 1.

A total of 73/269 (27.1\%) postal workers referred that dog owners usually keep their dogs loose on the streets in the neighborhood they work, and 187/270 (69.3\%) answered that owners keep their dogs locked behind fence, inside the household. A total of 263/282 (93.3\%) considered dogs as a problem to their work due not only to dog bites, but also to traffic accidents with motorcycles and cars during mail delivery and the stress caused by the constant barking to postal workers during their daily work. A high proportion of the postal workers, 257/281 $(91.5 \%)$, reported have been unable to execute their work due to the presence of dogs, of which $101 / 257(39.3 \%)$ had to suspend the work in the entire street due to the presence of dogs in the street. A total of 137/283 (48.4\%) postal workers believed that installing "beware of the dog" signs would not prevent the dog biting problem. A total of 195/283 (68.9\%) postal workers responded that dogs may transmit diseases to humans, of which 137/195 (70.3\%) mentioned rabies as one of the potentially transmitted diseases. Data regarding the general descriptive results of the postal workers are shown in Table 2.

\section{Discussion}

Characteristics of dog bite in postal workers is different than in the rest of the society due to their constant exposure to animals, probably making this population more susceptible to accidents involving dogs. Efforts to identify interventions in

Table 1. Characteristics regarding the postal workers that were ever bitten while working.

\begin{tabular}{lccc}
\hline \multicolumn{1}{c}{ Characteristic } & Total & $\%$ & IC 95\% \\
\hline $\begin{array}{l}\text { Bitten at least once while working } \\
\text { Number of times bitten while working }\end{array}$ & 197 & $69.61^{*}$ & $64.02-74.68$ \\
1 & & & \\
2 & 61 & 30.96 & $24.92-37.73$ \\
3 & 48 & 24.37 & $18.9-30.81$ \\
$>4$ & 34 & 17.26 & $12.62-23.15$ \\
Number of bites not reported & 35 & 17.77 & $13.06-23.71$ \\
Total number of bites reported & 19 & 9.64 & $6.26-14.57$ \\
Bitten on & 474 & $2.66 \pm 2.46^{* *}$ & - \\
Hands or feet & & & \\
Legs & 123 & 62.44 & $55.5-68.9$ \\
Arms & 99 & 50.25 & $43.33-57.16$ \\
Trunk & 29 & 14.72 & $10.45-20.34$ \\
Neck or head & 9 & 4.57 & $2.42-8.45$ \\
Different dog involved in different accidents & 1 & 0.51 & $0.09-2.81$ \\
Communicated the Post OfficeMailbox properly & 189 & $71.79^{* * *}$ & $63.05-79.16$ \\
installed & 96 & 95.93 & $92.19-97.92$ \\
\end{tabular}

* out of 283 postal workers that answered the questionnaire; ${ }^{* *}$ mean $\pm \mathrm{SD} ;{ }^{* * *} 84 / 117$ of postmen who reported being bitten more than once 
Table 2. General characteristics of the postal workers that answered the questionnaire.

\begin{tabular}{|c|c|c|c|c|c|c|}
\hline \multirow[b]{2}{*}{ Characteristic } & \multicolumn{3}{|c|}{ Bitten $(n=197)$} & \multicolumn{3}{|c|}{ Not bitten $(n=86)$} \\
\hline & $\begin{array}{l}\text { Number } \\
\text { answers }\end{array}$ & n (\%) & $95 \%$ IC & $\begin{array}{l}\text { Number } \\
\text { answers }\end{array}$ & n (\%) & $95 \%$ IC \\
\hline $\begin{array}{l}\text { Dogs roaming in the street } \\
\text { where in the working } \\
\text { neighborhood }\end{array}$ & 185 & $57(30.8)$ & $24.2-38.0$ & 83 & $16(19.3)$ & $11.4-29.4$ \\
\hline Consider dogs a problem & 194 & $184(94.8)$ & $90.7-97.5$ & 86 & $77(89.5)$ & $81.1-95.1$ \\
\hline $\begin{array}{l}\text { Dog have prevented from } \\
\text { working }\end{array}$ & 195 & $190(97.4)$ & $94.1-99.2$ & 85 & $66(77.6)$ & $67.3-86.0$ \\
\hline Can dogs cause diseases & 161 & $147(91.3)$ & $85.8-95.2$ & 59 & $48(81.4)$ & $69.1-90.3$ \\
\hline $\begin{array}{l}\text { Witness abuse of animals } \\
\text { while working }\end{array}$ & 163 & $40(24.5)$ & $18.1-31.9$ & 60 & $9(15.0)$ & $7.1-26.6$ \\
\hline Like dogs & 162 & $120(74.1)$ & $66.6-80.6$ & 62 & $52(83.9)$ & $72.3-92.0$ \\
\hline Have dogs or cats & 163 & $87(53.4)$ & $45.4-61.2$ & 62 & $43(69.4)$ & $56.3-80.4$ \\
\hline \multicolumn{7}{|l|}{$\begin{array}{l}\text { Best way to control animal } \\
\text { overpopulation }\end{array}$} \\
\hline Collection and euthanasia & 159 & $86(54.10$ & $46.0-62.0$ & 61 & $30(49.2)$ & $36.1-62.3$ \\
\hline Castration & 159 & $60(37.7)$ & $30.2-45.8$ & 61 & $27(44.3)$ & $31.5-57.6$ \\
\hline Adoption & 159 & $46(28.9)$ & $22.0-36.6$ & 61 & $16(26.2)$ & $15.8-39.1$ \\
\hline $\begin{array}{l}\text { Warning signs help avoiding } \\
\text { bites }\end{array}$ & 161 & $59(36.6)$ & $29.2-44.6$ & 60 & $26(43.3)$ & $30.6-56.8$ \\
\hline
\end{tabular}

order to reduce the dog biting problem have been world widely attempted ${ }^{24,25}$, but fully effectiveness may be restricted due to lack of reliable information. Although data analysis in the present study indicated that number of dog bites in a given neighborhood reported by postal workers is not related to population monetary income or population density, the event occurrence can be explained by those variables. The number of dogs in a given city or neighborhood can be estimated using the human population as a proxy ${ }^{26}$, and a higher number of dogs increases the likelihood of animals on streets, therefore also the dog bite risk. The inverse correlation identified in this study between income and bites can be explained by the possibility of acquiring better houses, fences, and even different kinds of households (apartments instead of houses), all which are expected to diminish the risk of a postal worker getting bitten. The data tested herein were not able to explain the number of bites in a given neighborhood, but authors believe that different kinds of households in different parts of cities may account for observed differences. Since this factor was not controlled in the present study, further studies are necessary to better investigate this hypothesis.

The response rate $(34.9 \%)$ observed might have brought some bias to our study, since post- al workers previously bitten and among those bitten, those that suffered more severe injuries or suffered more attacks, may have been more compelled to answer our questionnaire. Therefore, the proportion of postal workers that were bitten might be different in our sample than in the population, even though our project met the power sample calculation process. Despite that, comparing answers to non-specific questions of bitten and unbitten postal workers, general characteristics were similar.

The percentage of postal workers previously bitten while working highlights the dog biting problem affecting this class, similar to previously observed in an epidemiologic study of dog bites in Taiwanese postal workers ${ }^{24}$. No information regarding the time each postal worker has been working in the mail system was collected, therefore even though an increase in the risk of being bitten is expected for postal workers who have been working a longer time, a precise measurement of the risk should be further tested.

Besides the standard post-exposure rabies vaccination prophylaxis, decided in Brazil by the physician, it is reasonable to assume that some bitten postal workers might haveunderwent further medical assistance and given off-work days during the convalescence period. Even though this 
question was not the focus ofthe present study, dog biting problem may not be restricted to the biting itself. Among othermedical injuries related to dog bites, secondary infections are usually reported due to an extensive list of etiological agents, severe wounds that evolve to temporary or permanent disability and even death ${ }^{12,27}$. Noteworthy, 189/197 (95.9\%) postal workers that were bitten by dogs communicated the post office about the accident, mainly caused by moderateto-severe aggressions. The postal workers perception about dogs reflects their experiences while working. The relatively low percentage of postal workerswho believed that dogs may transmit diseases suggests that instructional lectures and training should be given to postal workers regularly as a work safety measure.Training of postal workers on animal behavior to avoid approaches that may trigger or increase the dog's aggression also is an important measure, both preventively and in face of an aggression. The authors suggest that the adoption of a dog repeller device, such as one that uses sound in a high pitch, might help the postal workers to deliver the mail without being harmed by the animals.

An effective prevention strategy for dog bite reduction among postal workers is very desir$\mathrm{able}^{24}$, since $90.5 \%$ of the postal workers were unable to execute their work and $39.5 \%$ had to suspend it on the entire street at least once while working. Besides, postal workers were bitten by both indoor and outdoor dogs, demonstrating that dogs confined inside the households may provide safety to postal workers while walking on streets, but not when mail is delivered into the mailbox.

Although $48.7 \%$ of the postal workers in the present study were bitten while delivering mail to houses with mailboxes correctly installed, these events could have been caused by either outdoor dogs or indoors dogs through the fence while the postal worker's body parts, particularly hands, were reachable. In a previous study of dog bite circumstances in New Zealand, only specific law enforcement on adequate property fencing by dog owners could have prevented a reasonable proportion of dog bites ${ }^{28}$. Therefore, only a correct installation of the mailbox associated to a fence high enough to avoid jumping and with narrowed gaps to avoid contact through fence would fully prevent dog bites. This study was not able to detect whether bites were less or more likely to occur at these homes since prevalence of this exposure (safe or unsafe mail boxes) was not the aim of the present study.
New Zealand also reported a high proportion of owners who usually allow dogs to freely roam on streets, according toone fourth of the interviewed postal workers ${ }^{28}$. As observed in Brazil, this country's cultural behavior may increase not only dog bites but also the transit accidents rates and disease transmission. Although important to establish awareness of local population, previous evidence suggested that educational dog ownership programs may not be effective when used as the only strategy to reduce dog bite injuries $^{29}$. On the other hand, government regulations have been associated with a significant decrease in injuries caused by dog bites ${ }^{25}$, indicating that educational campaigns on responsible dog ownership should be widely employed in association to regulatory enforcement and monitoring, as previously demonstrated ${ }^{15,30}$.

Due to resource limitations, we were not able to design a direct measurement of pet population at the time of the study. As we were not able to control the number of dogs on each neighborhood, it could have somehow affected the number of bites in postal workers. Since demographic data regarding human population are more frequently collected, the population density as a proxy of dog population in a given neighborhood was considered more reliable than indirect sources such as postal workers reports. Even though the number of dogs may not be necessarily related to population density due to inhabitation characteristics of each neighborhoods that could easily affect the population density, the lack of specific demographic data that take that into consideration forced the use of human population density as the proxy for dog population. The Brazilian rabies pet vaccination program estimates the number of dogs in a given city based on number of people in a given area, even though this proportion may fluctuate among different neighborhoods or cities ${ }^{26}$, which strengthens the present methodology. Moreover, such limitation does not change the importance of the socio-economic and prevention findings of our study, which may provide key information to legislators and public health professionals for the designing of effective public policies regarding dog bites in postal workers.

\section{Conclusion}

The occurrence of dog bites in postal workers of Curitiba, Brazil, is related to population monetary income and to population density, even 
though the number of biting episodes cannot be explained by these factors. Prevention should address the mailbox position and adequate fence to safely provide postal workers protection. Educational activities with local community population may be important to raise awareness of keeping own dogs restrained. Also, postal worker training onanimal behavior may help to avoid wrong approaches and dog aggressiveness.

\section{Collaborations}

EA Oliveira, PC Marcenovicz, LN Kuritza and HLB Ventura, designed the study and collected data. RM Manosso and G Braune had the original idea and collected data. IAD Paploski and M Kikuti analyzed data, translated and wrote the final manuscript. AW Biondo designed, analyzed and translated the final manuscript. 


\section{References}

1. Baun MM, Oetting K, Bergstrom N. Health benefits of companion animals in relation to the physiologic indices of relaxation. Holist Nurs Pract 1991; 5(2): 16-23.

2. Havener L, Gentes L, Thaler B, Megel ME, Baun MM, Driscoll FA, Beiraghi S, Agrawal S. The effects of a companion animal on distress in children undergoing dental procedures. Issues Compr Pediatr Nurs 2001; 24(2):137-152.

3. Williams AF, Wells JK. Characteristics of vehicleanimal crashes in which vehicle occupants are killed. Traffic Inj Prev 2005; 6(1):56-59.

4. Keuster TD, Lamoureux J, Kahn A. Epidemiology of dog bites: A Belgian experience of canine behaviour and public health concerns. Vet J 2006; 172(3):482-487.

5. Raghavan M. Fatal dog attacks in Canada, 19902007. Can Vet J 2008; 49(6):577-581.

6. Rowden P, Steinhardt D, Sheehan M. Road crashes involving animals in Australia. Accid Anal Prev 2008; 40(6):1865-1871.

7. Cornelissen JMR, Hopster H. Dog bites in The Netherlands: A study of victims, injuries, circumstances and aggressors to support evaluation of breed specific legislation. Vet J 2010; 186(3):292-298.

8. Benítez A, Rodrigues GG, Gonçalves DD, Burke JC, Alves LA, Müller EE, Freitas JC. Leptospirose em cães errantes encontrados em campus universitário: avaliação sorológica e exame direto de urina. Semina: Ciências Agrárias 2010; 31(1).

9. Wiwanitkit V. Dog-associated zoonosis. Prev Vet Med 2010; 95(1-2):163.

10. Acha P, Szyfres B. Zoonosis y enfermedades transmisibles comunes al hombre y a los animales. 3a Edición. Washington D.C.: Organización Panamericana de la Salud; 2001.

11. Buodo G, Ghisi M, Novara C, Scozzari S, Di Natale A, Sanavio E, Palomba D. Assessment of cognitive functions in individuals with post-traumatic symptoms after work-related accidents. J Anxiety Disord 2011; 25(1):64-70.

12. Jenkins SR, Auslander M, Conti L, Johnston WB, Leslie MJ, Sorhage FE. Compendium of animal rabies prevention and control, 2002. J Am Vet Med Assoc 2002; 221(1):44-48.

13. Gilchrist J, Sacks JJ, White D, Kresnow MJ. Dog bites: still a problem? Injury Prevention 2008; 14(5):296-301.

14. Buso DS, Nunes CM, Queiroz LH. Characteristics of biting animals submitted to rabies diagnosis, Sao Paulo State, Brazil, 1993-2007. Cad Saude Publica 2009; 25(12):2747-2751.

15. Ozanne-Smith J, Ashby K, Stathakis VZ. Dog bite and injury prevention-analysis, critical review, and research agenda. Inj Prev 2001; 7(4):321-326.

16. Nunes F. Carteiros sofrem com ataques de cães. $O$ Diário; 2008 [cited 2010 Sep 09]. Available from: http://www.odiario.com/maringa/noticia/200347/ carteiros-sofrem-com-ataques-de-caes.html

17. Myers JP. Bite Wound Infections. Curr Infect Dis Rep 2003; 5(5):416-425.
18. Brook I. Management of human and animal bite wound infection: an overview. Curr Infect Dis Rep 2009; 11(5):389-395.

19. Lopez J. Surveillance System for Infectious Diseases of Pets. Emerging Infectious Diseases 2009; 15(10): 1674-1676.

20. Matos MR, Alves MC, Reichmann Mde L, Dominguez MH. Sao Paulo Pasteur Institute Technique for estimating a canine population. Cad Saude Publica 2002; 18(5):1423-1428.

21. Instituto Brasileiro de Geografia e Estatística (IBGE). Censo 2010 - Total População Paraná. Brasília 2012 [cited 2011 Jan 03]. Available from: http://www. ibge.gov.br/home/estatistica/populacao/censo2010/ tabelas_pdf/total_populacao_parana.pdf

22. Fleiss JL. Statistical Methods for rates and proportions. New York: John Wiley; 1981.

23. IPPUC CUPaRI. Curitiba em Dados. Curitiba 2012 [cited 2011 Jan 3]; Available from: http://www. ippuc.org.br/Bancodedados/Curitibaemdados/ Curitiba_em_dados_Pesquisa.asp?ampliar=n\%E3o.

24. Chen SC, Tang FC, Lee HS, Lee CT, Yen CH, Lee MC. An epidemiologic study of dog bites among postmen in central Taiwan. Chang Gung Med J 2000; 23(5):277-283.

25. Villalbi JR, Cleries M, Bouis S, Peracho V, Duran J, Casas C. Decline in hospitalisations due to dog bite injuries in Catalonia, 1997-2008. An effect of government regulation? Injury Prevention 2010; 16(6): 408-410.

26. Reichmann MLAB, Pinto HBF, Nunes VFP. Vacinação contra a raiva de cães e gatos. Manual Técnico do Instituto Pasteur 1999; 3:1-32.

27. Deshmukh PM, Camp CJ, Rose FB, Narayanan S. Capnocytophaga canimorsus sepsis with purpura fulminans and symmetrical gangrene following a dog bite in a shelter employee. Am J Med Sci 2004; 327(6):369-372.

28. Wake AA, Stafford KJ, Minot EO. The experience of dog bites: a survey of veterinary science and veterinary nursing students. N Z Vet J 2006; 54(3):141-146.

29. Duperrex O, Blackhall K, Burri M, Jeannot E. Education of children and adolescents for the prevention of dog bite injuries. Cochrane Database Syst Rev 2009(2):CD004726.

30. Overall KL. Breed specific legislation: How data can spare breeds and reduce dog bites. The Veterinary Journal 2010; 186(3):277-279.

Artigo apresentado em 21/08/2012

Aprovado em 03/10/2012

Versão final apresentada em 29/10/2012 